\title{
Does partial privatisation improve performance? Evidence from a chain of hotels in Portugal
}

\author{
Carla A.F. Amado ${ }^{\mathrm{a}, *}$, Sérgio P. Santos ${ }^{\text {a }}$, Jaime M.M. Serra ${ }^{\mathrm{b}}$ \\ a Faculty of Economics and Center for Advanced Studies in Management and Economics (CEFAGE), Universidade do Algarve, Campus de Gambelas, 8005-139 Faro, Portugal

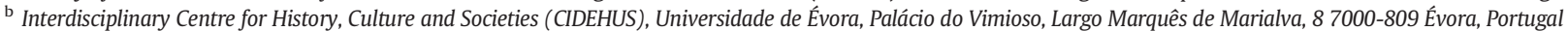

\section{A R T I C L E I N F O}

\section{Article history:}

Received 16 April 2015

Received in revised form 30 November 2016

Accepted 1 December 2016

Available online $\mathrm{xxxx}$

\section{Keywords:}

Privatisation

Performance

Efficiency

DEA

Malmquist productivity index

\begin{abstract}
A B S T R A C T
This article contributes to the literature by testing six research hypotheses regarding the impact of partial privatisation on firms' performance. We measure performance using Data Envelopment Analysis (DEA), the Malmquist Index and ratios related to labour productivity, profitability and capacity utilisation. We use the Wilcoxon Signed Rank test to compare the performance after privatisation with that before privatisation. The hypotheses are tested with data from a chain of Portuguese heritage hotels, partially privatised in 2003. We conclude that productivity growth after privatisation is superior to productivity growth before privatisation due to technological progress. However, due to a frontier regress observed in the privatisation year, total factor productivity and profitability deteriorated after privatisation. This suggests that both efficiency changes and frontier shifts should be taken into account in order to accurately assess the impact of privatisation.
\end{abstract}

(c) 2016 Elsevier Inc. All rights reserved.

\section{Introduction}

In recent years we have seen continued widespread privatisation of state-owned organisations across the world. Portugal has not been alien to this tendency and has witnessed several privatisation initiatives in different industries, such as banking, telecommunications, energy, postal services and hotels. However, the impact of these initiatives on firms' performance remains to be fully understood.

Investigating the impact of privatisation on performance is relevant because it is proposed that, if certain conditions are met, privatisation triggers change in the organisation, leading to improved performance (Boycko, Shleifer \& Vishny, 1996; Cuervo \& Villalonga, 2000).

When one is interested in studying the aggregate level of performance of an organisation or of a group of organisations, one may calculate its level of productivity and its level of production efficiency (Cooper, Seiford \& Tone, 2000). Productivity and production efficiency are related concepts, but have different meanings. Total factor productivity is a ratio of the weighted sum of outputs to the weighted sum of inputs (Cooper, Seiford \& Tone, 2000). Production efficiency is a measure of the distance to the best practice production frontier, given the current level of technology (Cooper, Seiford \& Tone, 2000). When we want to evaluate total factor productivity change, we need an index that accounts for two effects: the efficiency change effect and the frontier shift effect (Tone, 2004).

\footnotetext{
* Corresponding author.

E-mail addresses: camado@ualg.pt (C.A.F. Amado), ssantos@ualg.pt (S.P. Santos), jserra@uevora.pt (J.M.M. Serra).
}

A comprehensive review of the literature regarding the effects of privatisation on performance, undertaken by Megginson and Netter (2001), concluded that, whilst there is some evidence that privatisation improves performance, this evidence also suggests that this improvement is limited to certain indicators, and may affect negatively some stakeholders. Furthermore, the analysis of the literature also suggests that most studies have focused on the impact of privatisation on production efficiency, without paying due attention to the potential frontier shifts that may have taken place after privatisation.

Data Envelopment Analysis (DEA), developed by Charnes, Cooper and Rhodes (1978), is one of the most extensively used non-parametric techniques for measuring the production efficiency of homogeneous units. Although it was initially proposed to evaluate organisational efficiency, several studies have shown that this technique can also be useful in evaluating efficiency in specific management areas, such as marketing (see, for example, Dutta, Kamakura \& Ratchford, 2004; Donthu, Hershberger \& Osmonbekov, 2005; Luo \& Donthu, 2005) and finance (see, for example, Psillaki, Tsolas \& Margarities, 2010; Lamb \& Tee, 2012). For a recent survey on DEA applications the reader is referred to Liu, Lu, Lu and Lin (2013).

Despite the fact that several studies have used DEA to evaluate the performance of hotels and to investigate the determinants of performance (please refer to reviews undertaken by Assaf \& Josiassen, 2015 and by Santos \& Amado, 2014), to the best of our knowledge, no study has used this technique to analyse the impact of privatisation on the efficiency and/or the productivity of hotels. The study by Assaf and Cvelbar (2011) is the only published study that has investigated the 
impact of privatisation on the efficiency of hotels. In order to do so, they used the Stochastic Frontier Analysis (SFA) technique and the CobbDouglas and Translog functions to analyse expenses and sales in a sample of hotels. Based on the results of the analysis, they concluded that privatisation had a positive impact on the efficiency of Slovenian hotels and called for further studies of the accommodation industry. However, Assaf and Cvelbar (2011) did not study whether significant frontier shifts took place after privatisation and this is an important aspect to explore when studying the impact of privatisation.

This article aims to contribute to this body of literature by testing six research hypotheses regarding the impact of partial privatisation on the performance of hotels. In order to test these hypotheses, we use the non-parametric Wilcoxon Signed Rank test to compare the performance results after privatisation with those before privatisation. The hypotheses are tested with data from a chain of heritage hotels operating in Portugal, which was partially privatised in 2003 . Since $2003,49 \%$ of the capital of this chain became private and the chain is privately managed by a multinational group: Grupo Pestana Pousadas (GPP). A balanced panel of data from 2001 to 2010 was used in order to evaluate the impact of privatisation in terms of technological change, efficiency, total factor productivity and individual performance ratios.

By testing these hypotheses, this research makes the following contributions to the literature:

(1) By applying DEA to a panel set of data for a chain of enterprises we contribute to a better understanding of the impact of partial privatisation on organisational performance. Whilst most of the previous studies have only been able to undertake longitudinal analysis for a single company or had to combine data from companies in different countries and/or different industries, our study combines cross-sectional analysis with longitudinal analysis for a group of units belonging to the same industry and all privatised at the same time. This allows us to evaluate changes in total factor productivity, distinguishing between changes in the best practice frontier and changes in the efficiency of the individual units. This is an important contribution as analysing solely efficiency changes is insufficient to obtain a full understanding of the impact of privatisation on firms' performance as significant frontier shifts may occur.

(2) Considering that some studies have shown that not all performance dimensions improve after privatisation, we complement the total factor productivity analysis with a ratio analysis. By investigating changes in six relevant performance ratios we are able to identify the areas most affected by privatisation, as well as the direction of the changes.

(3) To the best of our knowledge, this is the first study that investigates the impact of privatisation on total factor productivity in the accommodation industry. By calculating the Malmquist Productivity Indices and their components before and after privatisation, we are able to study the impact of privatisation on total factor productivity and on each of its components.

The remainder of this paper is structured in six sections, as follows. Section 2 overviews the theoretical arguments and the empirical literature regarding the impact of privatisation on performance and sets the research hypotheses. Section 3 provides the background for the study, discussing the main characteristics of the hotel chain studied and the justification of its appropriateness to test the hypotheses. In Section 4 we discuss the methods used. In Section 5, we discuss the development of the DEA model used in this study, present summary statistics for the data used and present the results obtained. Section 6 discusses the results and the main contributions of this study, and Section 7 presents the main limitations of the study and provides suggestions for future research.

\section{Theory, literature review and hypotheses development}

\subsection{Impact of privatisation on total factor productivity}

As discussed by Chirwa (2001), there are several theoretical frameworks that support the view that private ownership is associated with better performance than public ownership. Chirwa (2001) discusses four arguments. Firstly, the property rights theory together with the principal-agent theory emphasise that the distance between the taxpayer and the manager of state-owned organisations makes monitoring more difficult and weakens the incentives for cost-minimisation. Secondly, the public choice theory suggests that state-owned enterprises pursue political objectives, such as maximisation of votes, employment, investment and budget control, which tend to lead to inefficiency. Thirdly, organisational theories argue that specific organisational characteristics of public enterprises (such as different management styles and organisational structures) tend to lead to inefficiency. Lastly, the soft budget constraint argument suggests that public enterprises, unlike private ones, are able to survive with prolonged losses given the government subsidies.

Boycko, Shleifer and Vishny (1996) present a theory of privatisation as a strategy to reduce the inefficiency of public enterprises. Several studies have empirically studied the impact of privatisation on the production efficiency of enterprises. These studies have used mainly two methods: (1) the parametric approach with SFA and (2) the non-parametric approach with DEA. Considering the advantages of DEA over SFA, in particular its ability to handle multiple inputs and multiple outputs without the need to specify a functional form for the production function, in this study we focus on the non-parametric approach with DEA.

We identified 17 studies that have used DEA to study the impact of privatisation on the production efficiency and/or the total factor productivity of firms. Table $\mathrm{S} 1$ in the supplementary material offers a synthesis of these studies, including information regarding the context and period of analysis, the methodology used and the main conclusions reached. This table has been split into two sections: Section 1 includes 11 studies that have investigated the impact of privatisation on production efficiency, and Section 2 includes six studies that have investigated the impact of privatisation on total factor productivity.

When we examine the information presented in Section 1 of Table S1 we find evidence that privatisation had a positive impact on the production efficiency of different companies, including: British Airways, British Gas and Associated British Ports (Boussofiane, Martin \& Parker, 1997), Nippon Telegraph and Telephone Corporation (Sueyoshi, 1998), a number of manufacturing enterprises in Malawi (Chirwa, 2001), a sample of German hospitals (Tiemann \& Schreyögg, 2012) and a sample of international airports (Assaf \& Gillen, 2012).

Despite the fact that improvements in production efficiency have been found in several different industries, some notes of caution regarding the difficulty in attributing these improvements solely to privatisation have been voiced in the literature. For example, despite observing positive impacts from full privatisation of the airports under certain conditions, Assaf and Gillen (2012) emphasised that deregulation appears to be more important than privatisation in order to improve airport efficiency.

Other notes of caution come from studies that found evidence of anticipation effects rather than privatisation effects. In these studies it was concluded that performance improved in the years immediately before privatisation, when the industries were rationalised and prepared for sale. Evidence of this effect was found in British Airways, British Airports Authority, British Steel (Boussofiane, Martin \& Parker, 1997) and in State-owned Canadian enterprises (Bozec \& Dia, 2003).

Although some studies have found evidence of positive impacts, there are others which could not find clear evidence of any discernible impact of privatisation on efficiency. Examples come from the telecommunications industry (Kang, 2009), the container port industry 
(Cullinane, Ji \& Wang, 2005), the transport industry (Parker, 1999), and the manufacturing sector (Abokaresh \& Kamaruddin, 2011).

Another note of caution regarding the impact of privatisation comes from the telecommunications, energy and transport industries in Spain. In trying to make sense of the results obtained in the Spanish context, Bachiller (2009, p. 303) emphasises that "the question is not the dichotomy of public versus private provider but, rather, the economic conditions under which services are delivered". In this respect, as suggested by Parker (1993), the existence of competition is considered a requisite for the achievement of improvements in production efficiency.

Cuervo and Villalonga (2000) proposed a dynamic model to explain the variation in the impact of privatisation on the performance of firms. According to this model, when certain conditions are met, privatisation triggers changes in goals, incentives and control mechanisms, which lead to changes in the strategy, structure and culture of the firm, resulting in improved performance. According to Cuervo and Villalonga (2000), a crucial condition for privatisation to lead to improvements in performance is the replacement of top management. The proposed model suggests that privatisation, when accompanied by top management replacement, prompts a firm to develop more innovative strategies and to undertake structural changes, due to the new capabilities, resources and mechanisms that are introduced in the firm. These authors also emphasise the importance of the existence of market competition in order to observe improvements in performance after privatisation.

We argue that access to new resources and capabilities and the pursuit of more innovative business strategies (as proposed by Cuervo \& Villalonga, 2000) may lead to technological progress (the best practice frontier shifts to superior levels of performance) and consequently to improvements in total factor productivity. In fact, there is some empirical evidence suggesting that privatisation leads to changes in total factor productivity (please, refer to Section 2 of Table S1).

Successful stories of a positive impact of privatisation on productivity have been reported from British Gas (Price \& Weyman-Jones, 1996), several Korean banks (Gilbert \& Wilson, 1998), Taiwan Motor Transport Company (Cho \& Fan, 2007) and from a sample of telecommunication companies across the world (Ariff, Cabanda \& Sathye, 2009). Parker and Wu (1998) found evidence of anticipation effects in the productivity of the British Steel Corporation.

On the contrary, Fethi, Shaban and Weyman-Jones (2011) provided evidence that privatisation is not sufficient to improve productivity in the banking sector. In fact, these authors offered evidence of a negative impact of privatisation on the productivity of Egyptian banks, which was explained by a regress of the best practice frontier.

Considering the theoretical arguments discussed previously and the lack of evidence regarding the impact of privatisation in the accommodation industry, this research aims to test the following research hypotheses:

H1. Partial privatisation of a chain of hotels operating in a competitive market, if accompanied by top management replacement, leads to technological progress;

H2. Partial privatisation of a chain of hotels operating in a competitive market, if accompanied by top management replacement, leads to improvements in production efficiency;

H3. Partial privatisation of a chain of hotels operating in a competitive market, if accompanied by top management replacement, leads to improvements in total factor productivity.

\subsection{Impact of privatisation on labour productivity, profitability and capac- ity utilisation}

In order to contribute to the opening of the black box regarding the impact of privatisation on performance in the accommodation sector, we consider that it is important to analyse the effect of privatisation on specific performance indicators. This will allow us to better understand the mechanisms through which performance may alter after privatisation.

Previous studies employing individual performance indicators have analysed the impact of privatisation on labour productivity and profitability in different sectors, having concluded, almost unanimously, that privatisation improves these indicators (please refer to the review by Megginson \& Netter, 2001). However, it is important to emphasise that previous studies have also concluded that the improvements observed in labour productivity and profitability usually come at the expense of job loss (see, for example, La Porta \& López-de-Silanes, 1999) and/or at the expense of higher prices to final consumers (see, for example, Newberry \& Pollitt, 1997), with their associated social costs.

Following the model proposed by Cuervo and Villalonga (2000), in addition to improvements in labour productivity and profitability, after privatisation, one would also expect to see improvements in output related indicators, due to control systems that are more market based. In the accommodation industry, revenue indicators and occupancy rates are important output indicators (Sigala, 2004; Huang, Mesak, Hsu \& Qu, 2012).

Based on these theoretical arguments, in order to better understand the effects of privatisation in the accommodation industry, we also aim to test the following three additional hypotheses:

H4. Partial privatisation of a chain of hotels operating in a competitive market, if accompanied by top management replacement, leads to improvements in labour productivity;

H5. Partial privatisation of a chain of hotels operating in a competitive market, if accompanied by top management replacement, leads to improvements in profitability;

H6. Partial privatisation of a chain of hotels operating in a competitive market, if accompanied by top management replacement, leads to improvements in capacity utilisation.

Having stated the hypotheses that we want to test in this study, we will now discuss the context that was chosen to test them.

\section{Background}

Travel and tourism is one of the main sectors of the Portuguese Economy, with a total contribution of 29.2 billion euros in 2015, representing $16.4 \%$ of the Gross Domestic Product (The Authority on World Travel and Tourism, 2016). The accommodation industry in Portugal is an important part of the Travel and Tourism sector and, in 2015, this industry generated 2.4 billion euros in revenue (Instituto Nacional de Estatística, 2016).

Pousadas de Portugal is a chain of heritage hotels created by the State in 1942 which, in November 2016, had 35 units. Despite representing a relatively small proportion of the accommodation industry in Portugal, this chain of hotels plays a central role in Portuguese society, due to its historic and cultural value, and its protection is considered of paramount importance.

This chain of hotels belongs to a holding company named Enatur, which had $49 \%$ of its capital privatised in 2003 . Following this initiative, since September 1st 2003, the chain has been managed by a multinational company (GPP). GPP belongs to the largest group operating in the Portuguese accommodation industry, namely Pestana Group. The hotels in the chain are equivalent to 4 and 5 star hotels and compete with other Portuguese hotels and with some long established and well known groups such as Ritz, Savoy, Sheraton, Holiday Inn and Marriott.

The privatisation of Enatur was motivated by its continuous and significant losses. The performance of this company has been previously analysed in Barros and Alves (2004), Barros and Mascarenhas (2005), and Barros (2005a, 2005b). These studies reported significant levels of 
inefficiency, suggesting that structural changes were needed to improve performance. In one of these studies (Barros \& Alves, 2004), privatisation had already been suggested as one of the solutions.

\section{Methods}

In order to evaluate the impact of the privatisation of Enatur on total factor productivity and its components, we used the non-parametric technique known as Data Envelopment Analysis, developed by Charnes, Cooper and Rhodes (1978). This technique uses a production metaphor. It considers that each Decision Making Unit (DMU) is engaged in a transformation process, where by using some inputs (resources) it is trying to produce some outputs (goods or services). DEA uses all the data available to construct a best practice empirical frontier, to which each inefficient DMU is compared. The best practice frontier is determined by the convex combination of the observations that achieve the highest weighted average of outputs to the weighted average of inputs. The efficiency of a firm in a specific period is, in turn, calculated by measuring the distance the firm is from the closest facet of the best practice frontier of that period. When measuring production efficiency with DEA one can assume an input orientation or an output orientation. With an input orientation, production efficiency is a measure of the distance between the current level of input usage and the minimum level of input that could be used to produce the current level of outputs (as given by the best practice frontier). When an output orientation is used, production efficiency is calculated from the distance between the current level of output production and the maximum level of output production that is feasible considering the level of resource usage and given the current technology.

Further to the specification of the model orientation, one must also specify a return to scale assumption in order to estimate the best practice frontier. If an increase in the inputs is expected to lead to a proportional increase in the outputs, a Constant Returns to Scale (CRS) assumption is appropriate, as proposed by Charnes, Cooper and Rhodes (1978). On the contrary, if a variation in the inputs is not expected to lead to proportional increases in the outputs, then a Variable Returns to Scale (VRS) assumption is appropriate, as proposed by Banker, Charnes and Cooper (1984). When a VRS assumption is used, one may also run a model with the CRS assumption in order to study the level of scale inefficiency present in the sample. Scale efficiency is calculated by dividing the scores obtained from the model with the CRS assumption by the scores obtained with the model with the VRS assumption. By using a VRS assumption, one estimates a measure of pure technical efficiency which is only influenced by the effect of managerial efficiency. When a CRS assumption is used one calculates a measure of technical efficiency, which combines the effects of managerial efficiency with the effects of scale efficiency.

Appendix A presents the mathematical formulation of the DEA models used to calculate the relative efficiency of each DMU, with a CRS assumption and an output orientation.

DEA can also be used to assess productivity changes over time through the calculation of the Malmquist Productivity Index (MPI) and its components (Caves, Christensen \& Diewert, 1982; Färe, Grosskopf, Lindgren \& Roos, 1994; Malmquist, 1953). The MPI is "an index representing Total Factor Productivity growth of a DMU, in that it reflects progress or regress in efficiency along with progress or regress of the frontier technology over time under the multiple inputs and multiple outputs framework" (Tone, 2004, p. 203).

In order to better understand how the MPI measures changes in total factor productivity, it is important to explain how it is calculated. The MPI is calculated by multiplying two indices: the 'frontier shift index' (F) and the 'catch-up effect index' (C).

The 'frontier shift index' captures the change in the efficient frontier from one period to another. This index is also known as technological change, considering that a shift in the frontier allowing a higher level of performance is usually the result of technological progress or some other type of innovation. In order to calculate the 'frontier shift index' it is necessary to evaluate the observations of firms operating in one period with regards to the frontier of the other period. If this index is equal to one for a particular firm, it means that the best practice frontier that is closest to the observation for this firm has not shifted. Alternatively, if this index is superior (inferior) to one, it means that the best practice frontier that is closest to the observation for the firm under analysis has shifted towards higher (lower) levels of performance.

The 'catch-up index' is measured by comparing the efficiency rate observed for a firm in one period with the efficiency rate of that firm in the preceding period. If this index is equal to one, it means that the firm is at the same distance to the best practice frontier. If it is superior (inferior) to one, it means that the efficiency rate of the firm increased (decreased) from one period to the other.

The calculation of the MPI and of its two components ( $F$ and $C$ ) for the period before privatisation and for the period after privatisation will allow us to test our first group of hypotheses (H1, H2 and H3).

The mathematical formulation used to calculate the MPI index and each of its two components is presented in Appendix B.

Although DEA can provide significant insights into the impact of privatisation on performance, Thanassoulis, Boussofiane and Dyson (1996) suggest that ratio analysis can complement the information obtained with DEA, as it can identify the specific areas of performance that require closer attention. In this respect, following the theory regarding the most important indicators in the accommodation context (see, for example, Huang, Ho \& Chio, 2014; Min, Min \& Joo, 2008; Peng, Huang \& Wu, 2013), and constrained by data availability, six performance ratios were calculated, as described below:

1) Rev per worker = Total revenue/Full Time Equivalent workers;

2) $\operatorname{Rev}$ to costs = Total revenue/Labour and operational costs;

3) Room rev to costs = Room related revenue and miscellaneous revenue/Labour and operational costs;

4) F\&B rev to costs = Food \& beverage revenue/Labour and operational costs;

5) $\operatorname{RevPar}=$ Room related revenue and miscellaneous revenue/Rooms available;

6) Occupancy rate $=$ Rooms occupied/Rooms available.

These six ratios cover three different areas of performance: ratio 1 relates to labour productivity, ratios 2, 3, 4 and 5 relate to profitability and ratio 6 relates to capacity utilisation, allowing us to test the second group of hypotheses (H4, H5 and H6).

In order to examine whether a significant difference exists between the performance in the period before privatisation and the performance in the period after privatisation, we use Wilcoxon signed rank tests, as proposed by Wilcoxon (1945). Appendix C provides a detailed description of the steps involved in carrying out this statistical test in the context under study.

The reasoning behind the Wilcoxon Signed Rank test is relatively simple. In our study, the null hypothesis is that the median difference between the performance observed before privatisation and after privatisation is equal to zero. If the null hypothesis is true, we expect the distribution of differences in performance to be approximately symmetrical around the null value; that is, whilst some firms may have improved their performance, others would have deteriorated. Furthermore, we would not expect the firms that have improved (or deteriorated) their performance to appear systematically at higher or lower ranks. In this respect, the sum of the ranks should be approximately equal, without extreme values in one of the sums. If an extreme value is observed in one of the sums, it means that there is a high probability that the null hypothesis of no performance differences is rejected.

The advantage of using this non-parametric statistic to test for differences in the performance results over the use of the parametric statistical tests proposed by Banker and Natarajan (2004) is that it requires fewer assumptions about the distribution of inefficiency and can be 
applied in small samples. As emphasised by Banker (1993), only in large samples can the distributional assumptions imposed for the true inefficiency variable be carried over to the empirical distribution of the DEA estimator of inefficiency in order to perform parametric statistical tests.

\section{Studying the impact of partial privatisation on the performance of Pousadas de Portugal}

\subsection{The DEA model used}

As discussed by Pedraja-Chaparro, Salinas-Jiménez and Smith (1999), the choice of appropriate inputs and outputs is a fundamental step in DEA given that the efficiency scores tend to be sensitive to this choice.

Having in mind the type of variables used in previous DEA studies (see, for example, Yu \& Lee, 2009; Assaf \& Josiassen, 2015), following the advice provided in Dyson, Allen, Camanho, Podinovski, Sarrico and Shale (2001), and constrained by data availability for the period studied, we developed the DEA model presented in Fig. 1, which has four inputs and two outputs.

The variables included in the model capture the essential elements of hotel operations, both in terms of resources used (capital and labour) and services delivered.

The first input represents a proxy for capital, as used in previous studies (see, for example, Barros 2005a, Chen 2013). Another proxy for capital that would have been relevant to include is the book value of property. However, we could not access data for this input for the whole period analysed. The second input captures the total number of nights that were available for sale during the years under analyses. This input is a function of the number of rooms available in the hotel, being a determinant for revenue generation. The third input represents the Full Time Equivalent (FTE) workers which accounts for the labour resources of the hotels. The fourth input represents the labour and operational costs, which account for the large majority of costs incurred by these hotels. External costs could also have been incorporated in the analysis, but we could only access reliable data for this variable for the period of 2006-10. For this period, this type of costs represented only $3 \%$ of the total costs, and their inclusion would not have a significant impact in the aggregate results obtained for the chain in these five years.

The two outputs represent the total sales of each hotel, separated by type. We have decided to separate the sales into two groups: those related with rooms and other types of sales (internet, souvenirs, etc.) and those related with food and beverages. This decomposition follows the decomposition made by the accounting department of the chain and allows for trade-offs between these two activity areas.

All the monetary variables were included at 2001 constant prices in order to allow a comparison between the different years.

A DEA model with an output-orientation was used, because it was considered that hotels should aim to maximise revenue levels based on their current capital and labour structure. With regards to returns to scale, we used a CRS assumption. This was considered appropriate as, in a separate analysis, we concluded that scale efficiency remained relatively stable during this period (no significant change in the level of scale efficiency was identified by Wilcoxon Signed Rank tests). Furthermore, as discussed in the DEA literature (see, for example, Sueyoshi \& Sekitani, 2009), only the model proposed by Charnes, Cooper and Rhodes (1978), with a CRS assumption, can satisfy the property of frontier shift measurability. In this respect, considering that one of our main objectives is to identify potential shifts in the best practice frontier, we chose to use a DEA model with a CRS assumption.

\section{Data and results}

In order to test the research hypotheses formulated, we used data provided by GPP for the period of 2001 to 2010 for a sample of 26 hotels belonging to the Pousadas de Portugal chain. This is a balanced panel of data with 260 observations corresponding to the 26 hotels that operated in the 10 year period analysed (two years prior to privatisation, privatisation year and seven years after privatisation). Despite efforts to obtain data regarding more years prior to privatisation, no reliable data could be obtained for the years prior to 2001 .

Table 1 presents the yearly descriptive statistics of data for the 26 hotels compared between 2001 and 2010. All monetary values are presented in euros and relate to 2001 constant prices, in order to allow comparisons of the pre-privatisation period with the post-privatisation period.

From Table 1 it is possible to verify that the total area of the hotels did not change during the ten year period analysed. However, when we look at the number of FTE workers, we can confirm that the number of workers decreased significantly after privatisation. Specifically, whilst in 2002, the average number of FTE workers was approximately 31, in 2010 this number had decreased to 21 . Furthermore, the minimum and maximum FTE workers also show a significant decrease, from a minimum of 20 and a maximum of 53 in 2002, to a minimum of 4 and a maximum of 35 in 2010.

When we analyse the descriptive statistics of cost data, we observe an increase in labour and operational costs in the privatisation year, followed by a regular decrease in the years after privatisation. With regards to revenue, we observe a general tendency for both types of revenue to decrease during the ten year period studied.

Having discussed the summary statistics of our data, we will now present and discuss the results obtained in the analysis carried out to test each of the six hypotheses formulated. In this presentation and discussion we focus on change rather than absolute performance values, as the latter are more prone to have been influenced by exogenous factors.

\subsection{Changes in total factor productivity (testing $\mathrm{H} 1, \mathrm{H} 2$ and $\mathrm{H} 3$ )}

In order to get a full picture regarding the evolution of productivity during the ten year period studied, we have calculated the cumulative MPI for the chain, using 2001 as the base year. Fig. 2 presents the evolution of the geometric mean of the cumulative MPI for the chain and of each of its two components. Consistent with previous studies (see, for example, Fethi, Shaban \& Weyman-Jones, 2011), the geometric mean is used as this is the most suitable measure when we want to average indices.

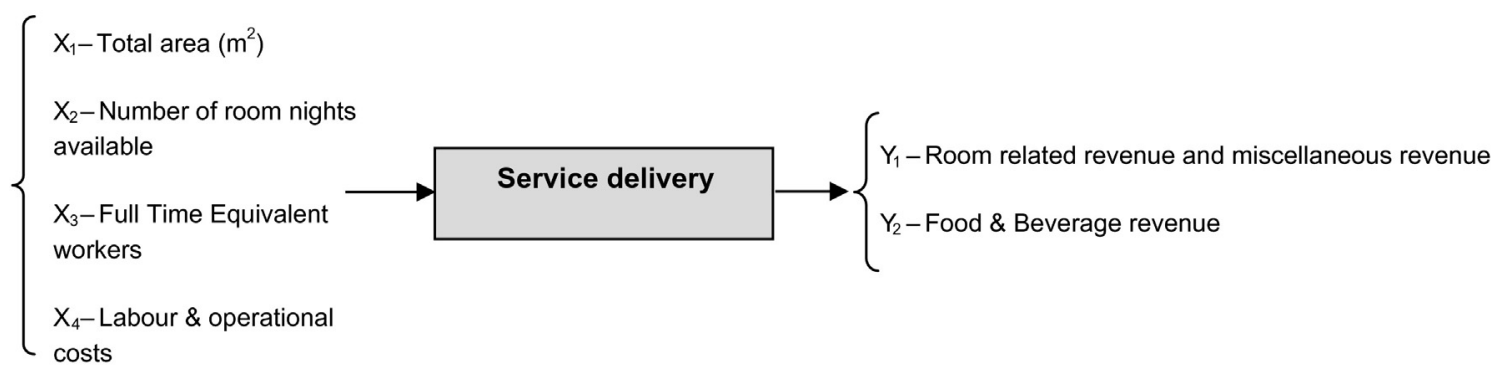

Fig. 1. DEA Model used to evaluate the level of productivity of the hotels. 
Table 1

Descriptive statistics of the data for the 26 hotels between 2001 and 2010.

\begin{tabular}{|c|c|c|c|c|c|c|c|c|c|c|}
\hline Variables & 2001 & 2002 & 2003 & 2004 & 2005 & 2006 & 2007 & 2008 & 2009 & 2010 \\
\hline \multicolumn{11}{|l|}{$\mathrm{X} 1$ - Area } \\
\hline Mean & 4054.12 & 4054.12 & 4054.12 & 4054.12 & 4054.12 & 4054.12 & 4054.12 & 4054.12 & 4054.12 & 4054.12 \\
\hline St Dev & 2291.61 & 2291.61 & 2291.61 & 2291.61 & 2291.61 & 2291.61 & 2291.61 & 2291.61 & 2291.61 & 2291.61 \\
\hline Min & 973 & 973 & 973 & 973 & 973 & 973 & 973 & 973 & 973 & 973 \\
\hline Max & 8099 & 8099 & 8099 & 8099 & 8099 & 8099 & 8099 & 8099 & 8099 & 8099 \\
\hline Range & 7126 & 7126 & 7126 & 7126 & 7126 & 7126 & 7126 & 7126 & 7126 & 7126 \\
\hline \multicolumn{11}{|c|}{ X2 - Room nights available } \\
\hline Mean & $10,335.58$ & $10,325.85$ & $10,146.19$ & $10,356.23$ & $10,577.27$ & $10,494.88$ & $10,585.92$ & $10,645.92$ & $10,023.42$ & $10,414.62$ \\
\hline St Dev & 3733.59 & 3658.16 & 3452.23 & 3894.06 & 4047.5 & 4181.16 & 4223.99 & 4264.89 & 4116.12 & 4390.92 \\
\hline Min & 3285 & 3285 & 3033 & 3261 & 3285 & 3285 & 3276 & 3289 & 3285 & 3174 \\
\hline Max & 18,615 & 17,541 & 17,520 & 18,666 & 18,615 & 18,615 & 18,615 & 18,666 & 18,615 & 18,615 \\
\hline Range & 15,330 & 14,256 & 14,487 & 15,405 & 15,330 & 15,330 & 15,339 & 15,377 & 15,330 & 15,441 \\
\hline \multicolumn{11}{|c|}{ X3 - FTE workers } \\
\hline Mean & 30.97 & 31.25 & 31.14 & 28.35 & 26.81 & 25.24 & 24.27 & 23.52 & 22.12 & 20.77 \\
\hline St Dev & 8.79 & 9 & 8.76 & 8.26 & 8.02 & 8.19 & 7.77 & 7.28 & 6.9 & 7.38 \\
\hline Min & 18.08 & 19.83 & 19.25 & 16.33 & 16.25 & 14.67 & 13.92 & 13.92 & 12 & 4 \\
\hline Max & 52.25 & 52.58 & 52.25 & 52.42 & 51.17 & 49.58 & 44.58 & 44.42 & 41 & 35 \\
\hline Range & 34.17 & 32.75 & 33 & 36.09 & 34.92 & 34.91 & 30.67 & 30.5 & 29 & 31 \\
\hline \multicolumn{11}{|c|}{ X4 - Labour \& operational costs } \\
\hline Mean & $781,197.96$ & $759,590.19$ & $805,512.77$ & $785,760.08$ & $763,976.65$ & $739,858.31$ & $718,902.04$ & $699,487.42$ & $622,924.73$ & $594,095.08$ \\
\hline St Dev & $282,675.12$ & $256,186.09$ & $251,352.06$ & $262,575.41$ & $260,977.4$ & $249,498.16$ & $250,624.47$ & $236,103.6$ & $209,718.06$ & $209,192.61$ \\
\hline Min & 422,817 & 449,503 & 469,214 & 443,017 & 437,807 & 422,935 & 373,600 & 386,996 & 331,527 & 258,614 \\
\hline Max & $1,498,324$ & $1,306,547$ & $1,310,028$ & $1,510,078$ & $1,436,155$ & $1,395,181$ & $1,319,491$ & $1,234,345$ & $1,107,352$ & $1,021,366$ \\
\hline Range & $1,075,507$ & 857,044 & 840,814 & $1,067,061$ & 998,348 & 972,246 & 945,891 & 847,349 & 775,825 & 762,752 \\
\hline \multicolumn{11}{|c|}{ Y1 - Room \& other type of revenue } \\
\hline Mean & $513,291.5$ & $498,654.35$ & $421,730.54$ & $435,077.96$ & $421,759.08$ & $447,530.04$ & $453,237.04$ & $405,818.62$ & $359,843.88$ & $344,644.62$ \\
\hline St Dev & $228,223.98$ & $221,021.21$ & $176,086.79$ & $187,368.71$ & $190,267.9$ & $206,854.04$ & $219,732.26$ & $192,551.24$ & $181,578.23$ & $170,777.05$ \\
\hline Min & 228,052 & 240,136 & 206,836 & 222,188 & 179,718 & 183,427 & 192,580 & 189,464 & 134,888 & 138,827 \\
\hline Max & $1,085,517$ & $1,067,278$ & 905,345 & 845,341 & 845,488 & 905,722 & 932,674 & 824,408 & 770,230 & 694,893 \\
\hline Range & 857,465 & 827,142 & 698,509 & 623,153 & 665,770 & 722,295 & 740,094 & 634,944 & 635,342 & 556,066 \\
\hline \multicolumn{11}{|c|}{ Y2 - F\&B revenue } \\
\hline Mean & $484,253.08$ & $473,535.35$ & $425,005.19$ & $418,425.27$ & $431,220.38$ & $432,225.15$ & $431,312.73$ & $393,430.46$ & $334,021.19$ & $292,424.27$ \\
\hline St Dev & $237,073.95$ & $195,361.21$ & $150,590.59$ & $155,100.36$ & $158,062.51$ & $164,607.3$ & $187,218.43$ & $179,150.75$ & $150,241.91$ & $145,444.11$ \\
\hline Min & 209,678 & 229,244 & 199,228 & 194,494 & 215,185 & 222,784 & 205,252 & 179,954 & 140,653 & 47,743 \\
\hline Max & $1,289,593$ & 981,463 & 717,107 & 900,012 & 860,145 & 896,581 & $1,005,529$ & 904,903 & 749,680 & 709,487 \\
\hline Range & $1,079,915$ & 752,219 & 517,879 & 705,518 & 644,960 & 673,797 & 800,277 & 724,949 & 609,027 & 661,744 \\
\hline
\end{tabular}

When we analyse the results presented in Fig. 2, we can identify four different periods (pre-privatisation period: 2001-2002; privatisation year: 2003; post-privatisation period before the onset of the international crisis: 2004-2007 and economic crisis period: 2008-2010).

The pattern of evolution observed in each of the four periods identified suggests that privatisation and the onset of the economic crisis affected significantly the level of productivity of this chain. Another interesting aspect to notice from Fig. 2 is that, in the four periods, despite some alterations in the level of efficiency, the general pattern of evolution in productivity is mainly explained by frontier shifts.

Specifically, we observe that in the pre-privatisation period only small changes took place in the level of productivity (around 1\%

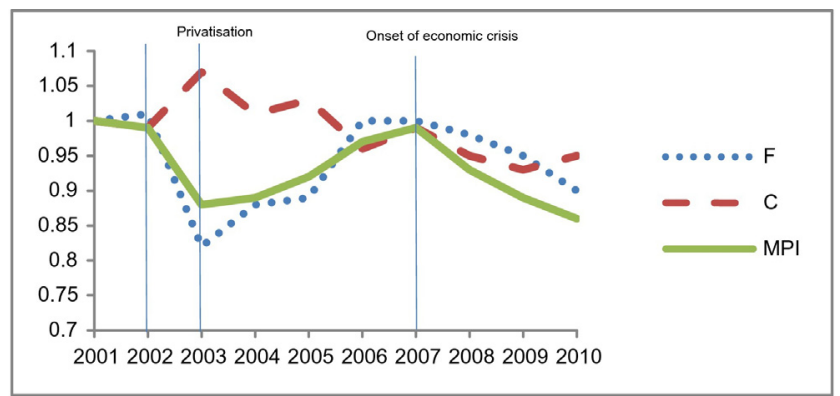

F - Frontier Shift (Technological Change); C - Catch - up effect (Efffiency Change); MPI - Malmquist Productivity Index

Fig. 2. Evolution of cumulative MPI for Enatur chain (2001 as base year). regress from 2001 to 2002). Contrasting heavily with the situation before privatisation, in the privatisation year we observe a strong detriment in productivity $\left(\mathrm{MPI}_{2001-2003}=0.88\right)$. This $12 \%$ regress in productivity can be explained by a strong technological regress $\left(F_{2001-2003}=0.82\right)$, which means that the efficient hotels suffered significantly and operated in 2003 at a level of performance that was, on average, $18 \%$ worse than that observed in 2001 . One can also notice that the average level of efficiency in 2003 was $7 \%$ higher than in 2001. However, this improvement needs to be interpreted with caution as this efficiency is in relation to a best practice frontier that is considerably inferior.

From 2003 onwards, we observe improvements in productivity (mainly explained by frontier shifts). Nevertheless, despite these improvements, it is only in 2006 and 2007 that the best practice frontier is at a similar level of performance to that observed in 2001. Considering that the inefficient hotels were not always able to catch up with the shifts of the best practice frontier, in aggregate terms, in 2007, the level of productivity was still 1\% below the level observed in 2001 .

As would be expected, due to the onset of the economic crisis, after 2007 we observe a decline in the best practice frontier of this chain and a consequent decline in productivity (MPI decreased 13\% from 2007 to 2010).

Considering the strong regress observed in the best practice frontier in the privatisation year, care needs to be taken in analysing the impact of privatisation on performance. A common methodology used in the literature to analyse the impacts of privatisation with longitudinal data (see, for example, Ariff, Cabanda \& Sathye, 2009) is to compare the average rates of change in performance from the pre-privatisation 
period to those observed in the post-privatisation period. This comparison allows us to test our first group of hypotheses:

H1. Partial privatisation of a chain of hotels operating in a competitive market, if accompanied by top management replacement, leads to technological progress;

H2. Partial privatisation of a chain of hotels operating in a competitive market, if accompanied by top management replacement, leads to improvements in production efficiency;

H3. Partial privatisation of a chain of hotels operating in a competitive market, if accompanied by top management replacement, leads to improvements in total factor productivity.

In this respect, in order to test $\mathrm{H} 1, \mathrm{H} 2$ and $\mathrm{H} 3$, we compare the performance of the hotels in the period before privatisation with the performance in the period after privatisation. More specifically, we contrast the rates of change in three separate periods. The first period is the pre-privatisation period: 2001 to 2002 ; the second period is the post-privatisation period before the onset of the international crisis: 2004-2007 (using the geometric mean of indices from 2004 to 2005; 2005-2006 and 2006-2007) and the third period is the economic crisis period: 2007-2010 (using the geometric means of indices from 2007 to 2008; 2008-2009 and 2009-2010). The changes around the privatisation year (from 2002 to 2003 and from 2003 to 2004) were not included in this comparison given that 2003 was a transformation year, with the influence of both public and private management (privatisation took place in September 2003). Fig. 3 contrasts the geometric mean values for the MPI and its components for these three periods.

When we contrast the three periods, we conclude that the strongest difference observed was in terms of frontier shift. Whilst in the period before privatisation, we could only observe an average shift in the best practice frontier of $1 \%$, in the period after privatisation this average rate of change was $5 \%$. Using the Wilcoxon signed rank tests, we can reject the null hypothesis (for $\mathrm{H} 1$ ) of a null median difference between the value of technological change in the period before privatisation and in the period after privatisation (two-sided $p$-value $=0.000$ ). In this respect, in the period after privatisation, before the onset of the economic crisis, we observe a higher rate of technological change than that observed before privatisation (the best practice frontier shifted towards higher levels of performance).

Inefficient hotels appear to have caught up with the best practice frontier, that is, the change in the average efficiency of the hotels being slightly higher in the post-privatisation period than in the preprivatisation period (although the difference in the efficiency change of the two periods is $<1 \%$ ). Using the Wilcoxon signed rank tests we cannot reject the null hypothesis (for $\mathrm{H} 2$ ) of a null median difference between the catch-up effect of the period before privatisation and the

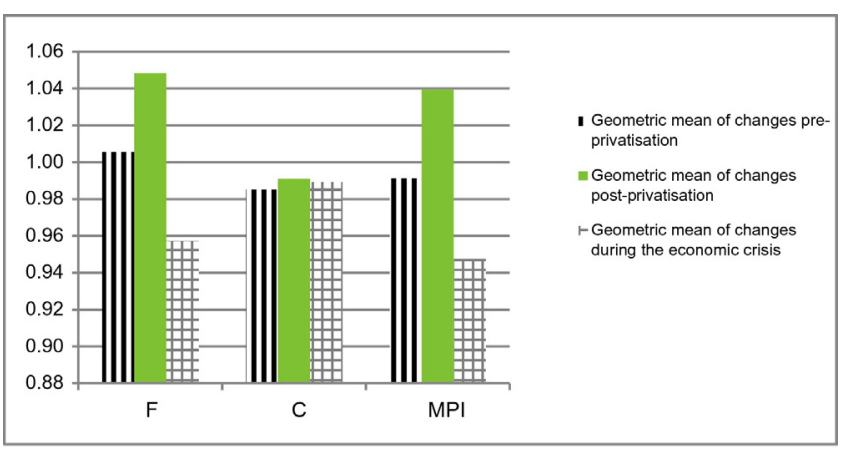

F - Frontier Shift (Technological Change); C - Catch-up effect (Efficiency Change); MPI - Malmquist Productivity Index

Fig. 3. Productivity changes before and after privatisation. catch-up effect of the period after privatisation (two-sided $p$-value $=$ 0.798). In this respect, our data does not support the hypothesis that production efficiency improves after the partial privatisation of hotels.

The combined result of these two effects is that, on average, productivity improved at a higher rate in the post-privatisation period when compared with the pre-privatisation period (the rate of improvement in productivity is $5 \%$ higher in the post-privatisation period). Using the Wilcoxon signed rank test, we can reject the null hypothesis (for $\mathrm{H} 3$ ) of a null median difference between the MPI before privatisation and the MPI after privatisation (two-sided $p$-value $=0.028$ ).

From Fig. 3, we can also confirm what would be expected in terms of the evolution of productivity after the start of the economic crisis. In this period we observe a regress in the best practice frontier. The Wilcoxon signed rank test identifies a significant change in the value of $\mathrm{F}$ (twosided $p$-value $=0.000$ ). Efficiency change after the onset of the economic crisis remains relatively stable when compared with the previous period (no significant change was identified with the Wilcoxon signed rank test, two sided $p$-value $=0.757$ ). The regress in the best practice frontier observed after the onset of the economic crisis results in a mean annual deterioration in the level of productivity of around 5\%. The Wilcoxon signed rank test allows us to reject the null hypothesis of a null median difference between the value of the MPI for the period after privatisation and the MPI for the period after the onset of the economic crisis (two-sided $p$-value $=0.000$ ).

Regarding the impact of partial privatisation on total factor productivity of hotels, our data suggest that significant improvements in productivity change may be expected due to technological progress. On the contrary, our data suggest that no significant improvements in efficiency change should be expected. However, care should be taken in analysing the full impact of privatisation because when a significant disruption is observed during the privatisation year, leading to a negative frontier shift, the level of accumulated productivity may take several years to recover.

\subsection{Changes in individual performance ratios (testing $\mathrm{H} 4, \mathrm{H} 5$ and $\mathrm{H6}$ )}

In order to analyse the separate effects of partial privatisation on labour productivity, profitability and occupancy rate, the following performance ratios were calculated:

1) Rev per worker $=$ Total revenue/FTE workers;

2) Rev to costs = Total revenue/Labour and operational costs;

3) Room rev to costs = Room related revenue and miscellaneous revenue/Labour and operational costs;

4) F\&B rev to costs = Food \& beverage revenue/Labour and operational costs;

5) RevPar $=$ Room related revenue and miscellaneous revenue/Rooms available:

6) Occupancy rate $=$ Rooms occupied/Rooms available.

The values observed for these performance ratios in the four periods (pre-privatisation; privatisation year; post-privatisation; economic crisis) were compared. Table 2 provides the descriptive statistics for the six performance ratios regarding the four different periods.

An analysis of the information presented in Table 2 provides interesting insights. From one period to the other, we observe that whilst the chain shows signs of improvement in some ratios, it shows signs of deterioration in others.

In order to make sense of this performance information, we analyse each group of the performance ratios in turn. When we look at the evolution of labour productivity (revenue per worker), we can see that this ratio deteriorates strongly in the privatisation year, improves strongly in the period after privatisation (to a level that is superior to that observed prior to privatisation), and deteriorates slightly during the economic crisis period.

A different pattern of behaviour is observed in the ratios related with profitability. The indicator of revenue that was most strongly affected 
Table 2

Descriptive statistics of the performance ratios in different periods.

\begin{tabular}{|c|c|c|c|c|c|c|c|c|c|}
\hline \multirow[t]{2}{*}{ Performance ratios } & \multirow[t]{2}{*}{$\mathrm{N}$} & \multicolumn{2}{|c|}{ Pre-privatisation period } & \multicolumn{2}{|c|}{ Privatisation year } & \multicolumn{2}{|c|}{ Post-privatisation period } & \multicolumn{2}{|c|}{ Economic crisis period } \\
\hline & & $\begin{array}{l}\text { Mean } \\
(2001-2002)\end{array}$ & $\begin{array}{l}\text { Std. Deviation } \\
(2001-2002)\end{array}$ & $\begin{array}{l}\text { Mean } \\
(2003)\end{array}$ & $\begin{array}{l}\text { Std. Deviation } \\
(2003)\end{array}$ & $\begin{array}{l}\text { Mean } \\
(2004-2007)\end{array}$ & $\begin{array}{l}\text { Std. Deviation } \\
(2004-2007)\end{array}$ & $\begin{array}{l}\text { Mean } \\
(2008-2010)\end{array}$ & $\begin{array}{l}\text { Std. Deviation } \\
(2008-2010)\end{array}$ \\
\hline Rev per worker (in euros) & 26 & $30,885.6$ & 5450.4 & $26,858.6$ & 4567.9 & $32,857.0$ & 6190.9 & $31,582.9$ & 6298.1 \\
\hline Rev to costs & 26 & 1.3 & 0.1 & 1.0 & 0.1 & 1.1 & 0.1 & 1.1 & 0.2 \\
\hline Room rev to costs & 26 & 0.7 & 0.1 & 0.5 & 0.1 & 0.6 & 0.1 & 0.6 & 0.1 \\
\hline $\mathrm{F} \& \mathrm{~B}$ rev to costs & 26 & 0.6 & 0.1 & 0.5 & 0.1 & 0.6 & 0.1 & 0.5 & 0.1 \\
\hline RevPar (in euros) & 26 & 50.6 & 19.5 & 43.5 & 17.9 & 43.7 & 18.7 & 37.0 & 15.8 \\
\hline Occupancy rate & 26 & $54.8 \%$ & $10.7 \%$ & $50.5 \%$ & $9.8 \%$ & $54.5 \%$ & $9.8 \%$ & $50.1 \%$ & $8.1 \%$ \\
\hline
\end{tabular}

both by the disruption during the privatisation year and by the onset of the economic crisis was RevPar. This is a ratio that indicates the average level of revenue per available room and it has reduced $27 \%$ from the preprivatisation period to the economic crisis period. The average occupancy rate remains almost constant from the pre-privatisation period to the post-privatisation period, showing some deterioration after the onset of the economic crisis.

Considering that the objective of this paper is to analyse the impact of privatisation, in order to test the second group of hypotheses ( $\mathrm{H} 4, \mathrm{H} 5$ and H6), we will now focus our analysis on contrasting the period before privatisation $(2001-2002)$ with that after privatisation (20042007) and will analyse the statistical significance of the changes observed by using the Wilcoxon Signed Rank tests. As previously discussed the three hypotheses that were formulated regarding changes in the performance ratios are:

H4. Partial privatisation of a chain of hotels operating in a competitive market, if accompanied by top management replacement, leads to improvements in labour productivity;

H5. Partial privatisation of a chain of hotels operating in a competitive market, if accompanied by top management replacement, leads to improvements in profitability;

H6. Partial privatisation of a chain of hotels operating in a competitive market, if accompanied by top management replacement, leads to improvements in capacity utilisation.

Table 3 provides the results for the Wilcoxon signed rank tests for the differences in the performance ratios between these two periods.

The information presented in Table 3 shows that when we compare the post-privatisation period with the pre-privatisation period in terms of the revenue per worker, we observe that the difference is statistically significant at the $1 \%$ significance level. This means that we reject the null hypothesis (for $\mathrm{H} 4$ ). We can also verify that the revenue per worker is much higher in the period after privatisation than in the period before privatisation (please refer to Table 2 ). With regard to profitability, the conclusion is different. Whilst we can reject the null hypothesis (for H5) regarding no profitability change, we can also verify that most of the ratios related to profitability show a statistically significant reduction after partial privatisation (please refer to Table 2). Specifically, the ratio of total revenue to costs decreased by $9.6 \%$. The type of revenue that was most affected was room related revenue, which decreased by
$12.2 \%$. Furthermore, RevPar also shows a statistically significant reduction of $13.6 \%$. With H6, we cannot reject the null hypothesis of no change in capacity utilisation after partial privatisation, because the occupancy rate remains almost constant, showing a reduction of $<1 \%$, which is not statistically significant.

Our data regarding a chain of heritage hotels operating in Portugal, for the six performance ratios analysed, suggests that after partial privatisation one should not expect a significant improvement in all performance ratios. Whilst we found evidence that average revenue per worker increased significantly from the period before privatisation to the period after privatisation, most of the profitability ratios deteriorated significantly after partial privatisation of the chain. Furthermore, our data did not identify a significant change in terms of the occupancy rate following partial privatisation.

\section{Discussion and conclusions}

Despite some notes of caution regarding the necessary conditions that need to be observed and regarding the potential social losses involved, the dominant theoretical arguments and a large number of empirical studies suggest that privatisation leads to improved performance. However, most of the previous empirical studies dedicated to this issue have focused on the impact of privatisation on production efficiency, ignoring the potential effects that privatisation may have on the best practice frontier and on total factor productivity.

In this study, we tested six hypotheses related with the impact of the partial privatisation of a chain of hotels. These hypotheses relate, on one side, with the impact of privatisation on total factor productivity, and, on the other side, with the impact of privatisation on labour productivity, profitability and occupancy rate.

Despite being a partial privatisation (51\% of the capital remained in the hands of the State), from 2003 onwards, $49 \%$ of the capital and the responsibility for top management of this chain was transferred to a private group with extensive experience in the accommodation industry. According to the model developed by Cuervo and Villalonga (2000), this change in top management, and the associated access to new capabilities and resources, should have triggered changes in the strategy, structure and culture of the hotels, leading to improved performance. Furthermore, considering that previous studies have suggested that market competition is a requisite for performance improvement after privatisation (Parker, 1993; Cuervo \& villalonga, 2000), the strong

Table 3

Wilcoxon signed rank tests for the differences in performance ratios from the period before privatisation to the period after privatisation.

\begin{tabular}{|c|c|c|c|c|c|c|}
\hline & $\begin{array}{l}\text { Rev per worker (after) - } \\
\text { Rev. per worker (before) }\end{array}$ & $\begin{array}{l}\text { Rev to costs (after) - } \\
\text { Rev. to costs (before) }\end{array}$ & $\begin{array}{l}\text { Room rev to costs (after) - } \\
\text { Room rev to costs (before) }\end{array}$ & $\begin{array}{l}\text { F\&B rev to costs (after) - } \\
\text { F\&B rev to costs (before) }\end{array}$ & $\begin{array}{l}\text { RevPar (after) - } \\
\text { RevPar before) }\end{array}$ & $\begin{array}{l}\text { Occupancy rate (after) - } \\
\text { Occupancy rate (before) }\end{array}$ \\
\hline $\mathrm{Z}$ & $-2.603^{\mathrm{a}}$ & $-4.153^{\mathrm{b}}$ & $-4.102^{b}$ & $-3.162^{b}$ & $-4.051^{\mathrm{b}}$ & $-0.749^{\mathrm{b}}$ \\
\hline Asymp. Sig. (2-tailed) & $0.009^{*}$ & $0.000^{*}$ & $0.000^{*}$ & $0.002^{*}$ & $0.000^{*}$ & 0.454 \\
\hline
\end{tabular}

a Based on negative ranks.

b Based on positive ranks.

* Means statistical significance at or below the $1 \%$ significance level. 
competition that exists in the hotel industry for 4 and 5 star rated hotels in Portugal makes this context an ideal setting to study the impact of privatisation.

Our results show that, on average, hotels were approximately $1 \%$ more efficient in the period after privatisation than they were in the period before privatisation, although this change is not statistically significant. Furthermore, we conclude that the rate of technological change was significantly higher in the post-privatisation period than in the pre-privatisation period (difference of $4 \%$ ). This significant frontier shift may be the result of the adoption of more advanced technology (for example, more sophisticated information systems), more advanced processes or better control mechanisms (as suggested by Cuervo \& Villalonga, 2000), by the hotels operating at the best practice frontier. Alternatively, these shifts may simply reveal a gradual resolution of the internal disruption caused by privatisation.

However, despite being statistically significant, this technological progress in the post-privatisation period was not enough to compensate for the strong negative effects that resulted from the internal disruption that affected this chain in the privatisation year. In 2007, the best performance year of the post-privatisation period analysed, just before the onset of the economic crisis, the level of productivity in this chain was still 1\% below the level observed in 2001 (two years before privatisation). Strong detrimental effects on productivity around the privatisation year have also been identified in privatisation studies analysing data from other countries (see, for example, Brown, Earle \& Telegdy, 2006). These authors justify these negative effects on productivity with the internal disruptions caused by privatisation.

Our analysis of the performance ratios of this chain reveals that the effect of privatisation on performance varies depending on the indicator used. The indicators that most suffered after privatisation are those related to revenue (RevPar decreased by $13.6 \%$ ) and profitability (the ratio of total revenue to costs decreased by $9.6 \%$ ) and the only performance ratio that improved after privatisation was labour productivity (the ratio of revenue per worker increased by $6.4 \%$ ). Meggison and Netter (2001) also found some evidence regarding the fact that privatisation effects differ depending on the performance indicators used. Furthermore, consistent with the results of other studies (for example, La Porta \& Lopéz-de-Silanes, 1999), we also found evidence of job losses after privatisation (an average of $16 \%$ reduction).

These results have relevance for researchers and policy makers as they suggest that caution is needed in a number of areas when analysing the effects of privatisation.

Firstly, our findings are relevant for researchers as they show that it is not sufficient to analyse the effects of privatisation on production efficiency, as significant frontier shifts may occur. In this respect, we suggest that an analysis of the effects of privatisation on total factor productivity and on its components should be undertaken. Furthermore, our results confirm that it is important to complement the measurement of productivity with an analysis regarding the areas of performance mostly affected by privatisation in order to study the separate effects of privatisation.

Secondly, our results are also significant for policy makers, as they shed some doubts regarding the expected positive impact of privatisation on the performance of enterprises. Our results suggest that Governments should carefully consider their decisions regarding the privatisation of enterprises, as the intended impact on performance may not be fully realised. Our results show that, on average, four years after partial privatisation, accompanied by the replacement of top management, heritage hotels operating in Portugal had not yet been able to fully recover from the strong regress in productivity observed during the privatisation year.

\section{Limitations of the study and suggestions for future research}

Whilst the results obtained enhance our knowledge on the impact of privatisation on the performance of organisations, it is important to bear in mind that they should be interpreted with caution for three main reasons: Firstly, this study analyses the effects of a partial privatisation programme (only $49 \%$ of the capital was privatised). Despite the top management team being replaced, the fact that the State kept $51 \%$ of the capital of the chain may have influenced the results. Secondly, the fact that our study focuses on a sample taken from one industry and one company limits the generalizability of the results regarding the impact of privatisation. Thirdly, this study suffers from some limitations related with the data available for analysis: on one side, it would have been useful to include data relating to a longer period before privatisation and it would also have been useful to include data regarding other variables (book value of properties, external costs and level of quality of the services provided); on the other side, the relatively small size of the sample used ( 26 hotels) inhibits more sophisticated analysis regarding the causes behind the results, such as a bootstrapped regression analysis as proposed by Simar and Wilson (2007).

Future studies should further investigate the impact of privatisation in this sector and in other sectors considering multiple performance dimensions (total factor productivity, quality and equity, if relevant) in order to better understand its effects, the stakeholders affected and the conditions under which privatisation may be associated with certain effects.

Supplementary data to this article can be found online at http://dx. doi.org/10.1016/j.jbusres.2016.12.001.

\section{Acknowledgements}

The authors are pleased to acknowledge financial support from FCT - The Portuguese National Funding Agency for Science, Research and Technology (Grant UID/ECO/04007/2013) and FEDER/COMPETE (POCI-01-0145-FEDER-007659) - CEFAGE (Carla Amado and Sérgio Santos) and COMPETE, FEDER, Portugal 2020 under the Project UID/ HIS/00057/2013 (POCI-01-0145-FEDER-007702) - CIDEHUS (Jaime Serra).

The authors are grateful to Graeme Doherty and to the anonymous reviewers for their insightful comments and helpful suggestions. The authors would also like to thank Grupo Pestana Pousadas for providing the data set.

\section{Appendix A. An introduction to data envelopment analysis}

Let us consider a general case characterised by the existence of $\boldsymbol{n}$ Decision Making Units $\left(\mathrm{DMU}_{j}, j=1, \ldots, n\right)$ to be compared, which use $\boldsymbol{m}$ inputs $\left(\boldsymbol{x}_{\boldsymbol{i}}, i=1, \ldots, m\right)$ to produce $\boldsymbol{s}$ outputs $\left(\boldsymbol{y}_{\boldsymbol{r}}, r=1, \ldots, s\right)$. The input weight or multiplier associated with input $\boldsymbol{i}$ is $\boldsymbol{v}_{\boldsymbol{i}}$ and the output weight or multiplier associated with output $\boldsymbol{r}$ is $\boldsymbol{u}_{\boldsymbol{r}}$. The objective of the Data Envelopment Analysis mathematical model (in its multiplier version) is to find the optimal weights for each input and output, in order to maximise the efficiency score of the DMU under assessment.

The output-oriented version of the mathematical model, in its multiplier version and in linear form, which should be used to calculate the Technical Efficiency of $\mathrm{DMU}_{0}$ is:

$\operatorname{Min} \sum_{i=1}^{m} v_{i} x_{i 0}$

Subject to:

$\sum_{\mathrm{r}=1}^{\mathrm{s}} \mathrm{u}_{\mathrm{r}} \mathrm{y}_{\mathrm{r} 0}=1$

$\sum_{r=1}^{s} u_{r} y_{r 0}-\sum_{i=1}^{m} v_{i} x_{i j} \leq 0, j=1, \ldots, n$.

$\mathrm{v}_{\mathrm{i}} \geq \varepsilon>0, \quad \mathrm{i}=1, \ldots, \mathrm{m}$

$u_{r} \geq \varepsilon>0, r=1, \ldots, s$ 
In order to obtain the scores of the $n$ DMUs under comparison, this mathematical model needs to be run $n$ times, once for each one of the $n$ DMUs.

\section{Appendix B. The Malmquist productivity index}

Consider that $\delta^{t_{2}}\left(\left(x_{Q}, y_{Q}\right)^{t_{1}}\right)$ with $t_{1}=1.2$ and $t_{2}=1.2$ represents the efficiency score of $\mathrm{DMU}_{\mathrm{Q}}$ operating in time period $t_{1}$, with reference to the frontier technology of period $t_{2}$, under the CRS technology.

Following Tone (2004), the 'catch-up index' (C) and the 'frontiershift index' (F) can be calculated using the following expressions:

$C=\frac{\delta^{2}\left(\left(x_{Q}, y_{Q}\right)^{2}\right)}{\delta^{1}\left(\left(x_{Q}, y_{Q}\right)^{1}\right)}$

$F=\left[\frac{\delta^{1}\left(\left(x_{Q}, y_{Q}\right)^{1}\right)}{\delta^{2}\left(\left(x_{Q}, y_{Q}\right)^{1}\right)} \times \frac{\delta^{1}\left(\left(x_{Q}, y_{Q}\right)^{2}\right)}{\delta^{2}\left(\left(x_{Q}, y_{Q}\right)^{2}\right)}\right]^{1 / 2}$

By multiplying both effects, we obtain the expression for the MPI:

$M P I=\left[\frac{\delta^{1}\left(\left(x_{Q}, y_{Q}\right)^{2}\right)}{\delta^{1}\left(\left(x_{Q}, y_{Q}\right)^{1}\right)} \times \frac{\delta^{2}\left(\left(x_{Q}, y_{Q}\right)^{2}\right)}{\delta^{2}\left(\left(x_{Q}, y_{Q}\right)^{1}\right)}\right]^{1 / 2}$

If the MPI is equal to one, it indicates that there was a status quo in the total factor productivity between the two periods analysed. Alternatively, if the MPI is smaller or greater than one, it indicates that there was decay or progress, respectively, in the total factor productivity.

\section{Appendix C. The Wilcoxon signed rank test}

The Wilcoxon Signed Rank test was proposed by Wilcoxon (1945). The following steps are involved in carrying out the Wilcoxon Signed Rank test to evaluate the statistical significance of the changes in performance from the period before privatisation to the period after privatisation:

1) Calculate the performance of each firm for the period before privatisation and for the period after privatisation. The scores of performance for each firm in the two periods constitute a pair of performance measures.

2) State the null hypothesis. In our study, the null hypothesis is that the median difference between the performance observed before privatisation and the performance observed after privatisation is equal to zero.

3) For each firm, calculate the difference between the performance after privatisation and the performance before privatisation.

4) Rank the absolute value of the paired differences between performance measures, attributing one to the smallest difference.

5) Attribute a positive or negative sign to each rank according to the value of the differences (if it is greater than zero, attribute a positive sign, if it is smaller than zero, attribute a negative sign). If the difference is null, ignore these observations and adjust the sample size accordingly.

6) Calculate the sums of the ranks of the positive differences and the sum of the ranks of the negative differences, and choose the smallest sum of ranks.

7) Compare the value observed for the smallest sum of ranks with the critical value for the Wilcoxon Signed Rank test, in order to calculate the probability of observing such a value (or a more extreme value) for the sum of ranks. Despite having formulated the research hypotheses with regards to improvements in performance after partial privatisation, we have used two-tailed tests in order to avoid the risk of failing to detect a negative effect.

\section{References}

Abokaresh, M. S. M., \& Kamaruddin, B. H. (2011). Performance rating of privatised and non-privatised firms using data envelopment analysis technique. Journal of Information Engineering and Applications, 1(4), 1-12.

Ariff, M., Cabanda, E., \& Sathye, M. (2009). Privatisation and performance: Evidence from telecommunications sector. Journal of the Operational Research Society, 60, 1315-1321.

Assaf, A. G., \& Cvelbar, L. (2011). Privatization, market competition, international attractiveness, management tenure and hotel performance: Evidence from Slovenia. International Journal of Hospitality Management, 30, 391-397.

Assaf, A. G., \& Gillen, D. (2012). Measuring the joint impact of governance form and economic regulation on airport efficiency. European Journal of Operational Research, 220, $187-198$.

Assaf, A. G., \& Josiassen, A. (2015). Frontier analysis: A state-of-the-art review and metaanalysis. Journal of Travel Research, 1-16. http://dx.doi.org/10.1177 0047287515569776.

Bachiller, P. (2009). Effect of ownership on efficiency in Spanish companies. Management Decision, 47(2), 289-307.

Banker, R. D. (1993). Maximum likelihood, consistency and data envelopment analysis: A statistical foundation. Management Science, 39(10), 1265-1273.

Banker, R. D., Charnes, A., \& Cooper, W. W. (1984). Some models for estimating technical and scale inefficiencies in data envelopment analysis. Management Science, 30, 1078-1092.

Banker, R. D., \& Natarajan, R. (2004). Statistical tests based on DEA efficiency scores. In W. W. Cooper, L. Seiford, \& J. Zhu (Eds.), Handbook on Data Envelopment Analysis (pp. 299-321). Boston: Kluwer Academic Publishers.

Barros, C. P. (2005a). Measuring efficiency in the hotel sector. Annals of Tourism Research, $32(2), 456-477$.

Barros, C. P. (2005b). Evaluating the efficiency of a small hotel chain with a Malmquist productivity index. International Journal of Tourism Research, 7, 173-184.

Barros, C. P., \& Alves, P. (2004). Productivity in tourism industry. International Advances in Economic Research, 10(3), 215-225.

Barros, C. P., \& Mascarenhas, M. J. (2005). Technical and allocative efficiency in a chain of small hotels. Hospital Management, 24, 415-436.

Boussofiane, A. S., Martin, S., \& Parker, D. (1997). The impact on technical efficiency of the UK privatisation programme. Applied Economics, 29, 297-310.

Bozec, R., \& Dia, M. (2003). L'impact de la commercialisation et de la privatisation sur l'efficacité technique des Sociétés d'État au Canada. Canadian Journal of Administrative Sciences, 20(4), 291-310.

Boycko, M., Shleifer, A., \& Vishny, R. W. (1996). A theory of privatisation. Economic Journal, 106(March), 309-319.

Brown, J. D., Earle, J. S., \& Telegdy, A. (2006). The productivity effects of privatization: Longitudinal estimates from Hungary, Romania, Russia, and Ukraine. Journal of Political Economy, 114(1), 61-99.

Caves, D. W., Christensen, L. R., \& Diewert, D. E. (1982). The economic theory of index numbers and the measurement of input, output, and productivity. Econometrica, 50, 1393-1414.

Charnes, A., Cooper, W. W., \& Rhodes, E. (1978). Measuring the efficiency of decision making unites. European Journal of Operational Research, 26(6), 429-444.

Chen, L. F. (2013). Research note: A sustainable hypothesis for tourist hotels: Evidence from international hotel chains. Tourism Economics, 19(6), 1449-1460.

Chirwa, E. W. (2001). Privatisation and technical efficiency: Evidence from the manufacturing sector in Malawi. African Development Review, 13(2), 276-307.

Cho, H. J., \& Fan, C. K. (2007). Evaluating the performance of privatisation on regional transit services: Case study. Journal of Urban Planning and Development, 133(2), 119-127.

Cooper, W. W., Seiford, L. M., \& Tone, K. (2000). Data envelopment analysis: A comprehensive text with models, applications, references and DEA-solver software. London: Kluwer Academic Publishers.

Cuervo, A., \& Villalonga, B. (2000). Explaining the variance in the performance effects of privatization. Academy of Management Journal, 43(5), 925-950.

Cullinane, K., Ji, P., \& Wang, T. (2005). The relationship between privatisation and DEA estimates of efficiency in the container port industry. Journal of Economics and Business, 57, 433-462.

Donthu, N., Hershberger, E. K., \& Osmonbekov, T. (2005). Benchmarking marketing productivity using data envelopment analysis. Journal of Business Research, 58(11), 1474-1482.

Dutta, S., Kamakura, W., \& Ratchford, B. T. (2004). Deterministic and stochastic approaches for assessing marketing efficiency. In C. Moorman, \& D. R. Lehmann (Eds.), Assessing marketing strategy performance. Marketing Science Institute: Massachusetts.

Dyson, R. G., Allen, R., Camanho, A. S., Podinovski, V. V., Sarrico, C. S., \& Shale, E. A. (2001) Pitfalls and protocols in DEA. European Journal of Operational Research, 132(2), 245-259.

Färe, R., Grosskopf, S., Lindgren, B., \& Roos, P. (1994). Productivity change in Swedish hospitals: A Malmquist output index approach. In A. Charnes, W. W. Cooper, A. Y. Lewin, \& M. L. Seiford (Eds.), Data envelopment analysis: Theory, methodology and applications (pp. 253-272). Boston: Kluwer Academic Publishers.

Fethi, M. D., Shaban, M., \& Weyman-Jones, T. (2011). Liberalisation, privatisation and the productivity of Egyptian banks: A non-parametric approach. The Service Industries Journal, 31(7), 1143-1163.

Gilbert, R. A., \& Wilson, P. W. (1998). Effects of deregulation on the productivity of Korean banks. Journal of Economics and Business, 50, 133-155.

Huang, C. W., Ho, F. N., \& Chio, Y. H. (2014). Measurement of tourist hotels' productive efficiency, occupancy, and catering service effectiveness using a modified two-stage DEA model in Taiwan. Omega, 48, 49-59. 
Huang, Y., Mesak, W. I., Hsu, M. K., \& Qu, H. (2012). Dynamic efficiency assessment of the Chinese hotel industry. Journal of Business Research, 65, 59-67.

Instítuto Nacional de Estatística (2016). Estatísticas do Turismo 2015. (Lisboa).

Kang, C. C. (2009). Privatisation and production efficiency in Taiwan's telecommunications industry. Telecommunications Policy, 33(9), 495-505.

La Porta, R., \& López-de-Silanes, F. (1999). The benefits of privatization: Evidence from Mexico. The Quarterly Journal of Economics, 114(4), 1193-1242.

Lamb, J., \& Tee, K. -H. (2012). Data envelopment analysis models for investment funds. European Journal of Operational Research, 216, 687-696.

Liu, J. S., Lu, L. Y. Y., Lu, W. -M., \& Lin, B. J. Y. (2013). A survey of DEA applications. Omega: The International Journal of Management Science, 4, 893-902.

Luo, X., \& Donthu, N. (2005). Assessing advertising media spending inefficiencies in generating sales. Journal of Business Research, 58, 28-36.

Malmquist, S. (1953). Index numbers and indifference surfaces. Trabajos de Estadística, 4, 209-242.

Megginson, W., \& Netter, J. M. (2001). From state to market: A survey of empirical studies on privatisation. Journal of Economic Literature, 39, 321-389.

Min, H., Min, H., \& Joo, S. J. (2008). A data envelopment analysis-based balanced scorecard for measuring the comparative efficiency of Korean luxury hotels. International Journal of Quality E Reliability Management, 25(4), 349-365.

Newbery, D. M., \& Pollitt, M. G. (1997). The restructuring and privatisation of the CEGB Was it worth it? The Journal of Industrial Economics, 45(3), 269-303.

Parker, D. (1993). Ownership, organizational changes and performance. In T. Clarke, \& C. Pitelis (Eds.), The political economy of privatization (pp. 17-30). London: Routledge.

Parker, D. (1999). The performance of BAA before and after privatisation: A DEA study. Journal of Transport Economics and Policy, 33, 133-146.

Parker, D., \& Wu, H. L. (1998). Privatisation and performance: A study of the British steel industry under public and private ownership. Economic Issues, 3(2), 31-50.

Pedraja-Chaparro, F., Salinas-Jiménez, J.. \& Smith, P. C. (1999). On the quality of the data envelopment analysis model. Journal of the Operational Research Society, 60, 636-644.

Peng, K. H., Huang, J. H., \& Wu, W. H. (2013). Rasch model in data envelopment analysis: Application in the international tourist hotel industry. Journal of the Operational Research Society, 64(6), 938-944.
Price, C. W., \& Weyman-Jones, T. (1996). Malmquist indices of productivity change in the UK gas industry before and after privatisation. Applied Economics, 28, 29-39. Psillaki, M., Tsolas, I., \& Margarities, D. (2010). Evaluation of credit risk based on firm performance. European Journal of Operational Research, 201, 873-881.

Santos, S. P., \& Amado, C. A. F. (2014, October). Performance measurement in the hospitality and tourism industry: Overview and future research directions. Paper presented at the 2014 tourism policy forum summit, Chiayi, Taiwan, 22nd of October 2014.

Sigala, M. (2004). Using data envelopment analysis for measuring and benchmarking productivity in the hotel sector. Journal of Travel \& Tourism Marketing, 16(2), 39-60.

Simar, L., \& Wilson, P. W. (2007). Estimation and inference in two-stage, semi-parametric models of production processes. Journal of Econometrics, 136, 31-64.

Sueyoshi, T. (1998). Privatisation of Nippon telegraph and telephone: Was it a good policy decision? European Journal of Operational Research, 107, 45-61.

Sueyoshi, T. \& Sekitani, K. (2009). An occurrence of multiple projections in DEAbased measurement of technical efficiency: Theoretical comparison among DEA models from desirable properties. European Journal of Operational Research, 196, 764-794.

Thanassoulis, E., Boussofiane, A., \& Dyson, R. D. (1996). A comparison of data envelopment analysis and ratio analysis as tools for performance assessment. Omega, 24(3), 229-244.

The Authority on World Travel \& Tourism (2016). Travel E tourism. Economic impact 2016. Portugal. London: World Travel \& Tourism Council.

Tiemann, O., \& Schreyögg, J. (2012). Changes in hospital efficiency after privatization. Health Care Management Science, 15(4), 310-326.

Tone, K. (2004). Malmquist productivity index: Efficiency change over time. In W. W. Cooper, L. M. Seiford, \& J. Zhu (Eds.), Handbook on data envelopment analysis (pp. 203-227). London: Kluwer Academic Publishers.

Wilcoxon, F. (1945). Individual comparisons by ranking methods. Biometrics Bulletin, $1(6), 80-83$.

Yu, M. M., \& Lee, B. C. Y. (2009). Efficiency and effectiveness of service business: Evidence from international tourist hotels in Taiwan. Tourism Management, 30, 571-580. 